\title{
La presencia del laísmo, leísmo y loísmo en seis relatos breves de Juan Arzadun, Juan de Irigoyen, Miguel Aranaz y Rafael Sánchez
}

\author{
Laismoa, leismoa eta loismoa Juan Arzadunen, Juan de Irigoyenen, \\ Miǵuel Aranazen eta Rafael Sánchezen sei kontakizun laburretan \\ Laísmo, leísmo and loísmo in six short stories by Juan Arzadun, \\ Juan de Irigoyen, Miguel Aranaz and Rafael Sánchez
}

\author{
Edurne Goñi Alsúa \\ Universidad Pública de Navarra / Nafarroako Unibertsitate Publikoa \\ edurne.goni@unavarra.es \\ https://orcid.org/0000-0002-7488-2689
}

\begin{abstract}
Resumen
Laísmo, leísmo y loísmo son tres fenómenos sintácticos recurrentes en la lengua castellana producidos por el uso erróneo de los pronombres personales átonos o clíticos. Estas variaciones de la norma se han estudiado extensamente a lo largo de la historia desde el punto de vista tanto sincrónico como diacrónico o funcional. No han faltado autores que han buceado en textos literarios para trazar su formación y desarrollo, los que se han servido de estas observaciones para anclarlos en su origen latino, o aquellos que los han investigado desde el contacto de lenguas y su realización por parte de hablantes bilingües. En este artículo, vamos a realizar un estudio textual en el que analizaremos estas tres variaciones de los pronombres clíticos en varios relatos breves, escritos en el primer tercio del siglo XX por cuatro autores vizcaínos, a saber, Juan Arzadun, Juan de Irigoyen, Manuel Aranaz Castellanos y Rafael Sánchez Mazas, como reflejo literario del uso de los pronombres átonos en el castellano de Bilbao, definido como dialecto leísta.
\end{abstract}

\section{Palabras clave}

Laísmo, leísmo, loísmo, relatos breves, vascuence.

\section{Sumario}

1. INTROdUCCIÓN. 2. Definición, CAUSAS y ORíGenes del fenómeno. 2.1. Definición. 2.2. Variaciones, duplicaciones y omisiones de pronombres clíticos y el sustrato vascuence. 3. CORPUS ANALIZADO Y ANÁLISIS LINGÜístICO. 3.1. Autores. 3.2. Corpus. 3.3. Análisis de las variaciones encontradas. 4. CONCLUSIÓN. REFERENCIAS. 


\begin{abstract}
Laburpena. Laismoa, leismoa eta loismoa izenordain pertsonal atono edo klitikoen okerreko erabilerak gaztelanian errepikatutako hiru fenomeno sintaktiko dira. Arauaren aldaketa horiek asko aztertu dira historian zehar, bai ikuspuntu sinkronikotik, bai diakronikotik edo funtzionaletik. Ez dira falta izan literatura-testuetan murgildu diren autoreak beren prestakuntza eta garapena taxutzeko; behaketa horiek erabili dituztenak latinezko jatorrian ainguratzeko, edo hizkuntzen kontaktuetatik eta hiztun elebidunen errealizaziotik ikertu dituztenak. Artikulu honetan, testu-azterketa bat egingo dugu, eta, bertan, izenordain klitikoen hiru aldaketa horiek aztertuko ditugu zenbait kontakizun laburretan, zeinak Bizkaiko lau autorek idatzi baitzituzten XX. mendearen lehen herenean (Juan Arzadun, Juan de Irigoyen, Manuel Aranaz Castellanos eta Rafael Sánchez Mazas), Bilboko gaztelaniako izenordain atonoen erabileraren literatura-isla gisa.
\end{abstract}

Gako hitzak. Laismoa, leismoa, loismoa, kontakizun laburrak, euskara.

\begin{abstract}
Laísmo, leísmo and loísmo are three syntactic variations produced in Spanish, due to the incorrect use of the unstressed personal pronouns. These deviations of the linguistic norm have been widely studied from the synchronic, diachronic or functional points of view. Even, some scholars have traced back their origin to the dative case of Latin. Another possibility to study this topic is from the point of view of bilingualism and language contact. In this article, we are going to develop a textual study in which we will analyse the laísmo, leísmo and loísmo in six short stories written at the beginning of the 20th century, by four writers from Biscai -Juan Arzadun, Juan de Irigoyen, Manuel Aranaz Castellanos and Rafael Sánchez Mazas-, as a literary reflection of the use of the afore mentioned unstressed personal pronouns.
\end{abstract}

Keywords. Laísmo, leísmo, loísmo, short stories, Basque.

«El lenguaje es el alma del individuo y del pueblo» Unamuno, 1958

\section{Introducción}

Una de las características del bilingüiismo es la transposición de elementos lingüuísticos que ocurren, especialmente, si el hablante es, de acuerdo con Lambert (1955), un bilingüe dominante, en el que el conocimiento de su lengua nativa sobrepasa el de la segunda lengua, aunque este concepto, de acuerdo con Treffers-Daller (2015), sea complejo de explicar porque requiere profundizar en el hecho de qué es ser bilingüue. Y es en esta conjunción de dos lenguas donde se sitúa el tema principal de este estudio: el uso de los pronombres clíticos de tercera persona en hablantes bilingües de vascuence y castellano y su reflejo en seis relatos cortos de cuatro autores vizcaínos.

En este trabajo se va a proporcionar un ejemplo de esta transposición reflejada en la literatura, centrándonos en el uso de los pronombres la, le, lo, y su desviación de la norma, así como su duplicación y omisión, partiendo de la afirmación de que el dialecto castellano del País Vasco es leísta. El corpus textual en el que nos vamos a basar está extraído de una serie de relatos breves de autores vascos, escritos todos ellos durante el primer tercio del siǵlo XX: «La artimaña»y 
«Cuentos vascos» de Juan Arzadun, «Los tremendos de Kanala» de Juan de Irigoyen, «La parrita»y «A patita» de Manuel Aranaz Castellanos y «La vida nueva de Pedrito de Andía» de R. Sánchez Mazas.

\section{Definición, causas y orígenes del fenómeno}

\subsection{Definición}

Por lo general, se considera que laísmo, leísmo y loísmo son desviaciones de la norma gramatical española que se deben evitar y corregir, aunque su uso está tan extendido, que incluso Fernández Ordoñez (1993) enumera una serie de escritores españoles en cuyas obras aparecen estos fenómenos.

La Academia de la Lengua Española define laísmo como ${ }^{1}$ :

1. m. Gram. Empleo de las formas la y las del pronombre átono para el complemento indirecto femenino, en lugar de le y les.

Es decir, el uso de la (acusativo) por le (dativo).

Esta misma institución explica que el leísmo² es:

1. m. Gram. Empleo de las formas le y les del pronombre átono para el complemento directo, en lugar de las formas lo, la, los y las.

El uso de le (dativo) en vez de lo y la (acusativo).

Y, por último, define el loísmo como³

1. m. Gram. Empleo de las formas lo y los del pronombre átono para el complemento indirecto masculino, en lugar de le y les.

Esto es, el empleo del pronombre lo (acusativo) en lugar le (dativo).

No obstante, la Academia ha aceptado el llamado leísmo de persona, o la posible utilización de le o lo cuando el complemento indirecto sea masculino singular. Abundando en esta idea, Fernández-Ordóñez (1993) expone que:

Los autores distinguen distintos tipos de leísmo: 1) el de objeto directo (OD) masculino, y dentro de él, el de OD personal, el más frecuente y extendido, y el de OD de cosa, de difusión más reducida; 2) el leísmo plural, según parece

1 http://dle.rae.es/?id=MogbQT1

2 http://dle.rae.es/?id=N5seX8M

3 http://dle.rae.es/?id=Na2QVer 
menos frecuente que el singular, y 3) el leísmo de OD femenino, normalmente personal, tanto singular como plural, muy raro. 4) No se documenta leísmo (salvo contadísimas excepciones) cuando el referente es neutro (p. 63).

El pronombre personal átono español es el único elemento morfológico que mantiene restos de declinación latina, ya que su «sistema etimológico conserva las distinciones del sistema latino» (Miranda, 1994, p. 353), como podemos apreciar en el siguiente cuadro:

\begin{tabular}{|cccc|}
\hline $\begin{array}{c}\text { Acusativo singular } \\
\text { CD }\end{array}$ & $\begin{array}{c}\text { Acusativo plural } \\
\text { CD }\end{array}$ & $\begin{array}{c}\text { Dativo singular } \\
\text { GI }\end{array}$ & $\begin{array}{c}\text { Dativo plural } \\
\text { CI }\end{array}$ \\
\hline masculino- illum $>$ lo & masculino- illos $>$ los & illi $>$ le & illis $>$ les \\
femenino- illam $>$ la & femenino- illas $>$ las & illi $>$ le & illi $>$ le \\
\hline neutro- illud $>$ lo & & illi $>$ le & illi $>$ le
\end{tabular}

De acuerdo con esta misma autora, «podemos observar a través del cuadro, cómo aparte de la inexistencia en el español del neutro plural y la indistinción del masculino y neutro en singular, los dos sistemas se corresponden» (Miranda, 1994, p. 353). De esta manera, apreciamos cómo en castellano las formas de acusativo distinguen género y número, mientras que las de dativo solo distinguen número.

El profesor Lapesa (1964) afirmaba que el leísmo tuvo su origen en el mantenimiento de la rección latina de dativo, debido a que estos casos tenían como referente lo personal. Más adelante, el proceso se amplió y le / les pasaron a llevar a cabo la función de complemento directo con referente de persona, con verbos que en latín no regían dativo, a lo que, posteriormente, se añadieron los casos de reinterpretaciones funcionales de otras construcciones latinas. Sin embargo, los primeros casos de leísmo son de referente personal y se iniciaron en textos del siǵlo XIII, llegando a su máximo apogeo en el siǵlo XVII, afirmación que también comparten Miranda (1994) y Fernández-Ordoñez (2001).

Abundando en el origen y evolución del uso de los pronombres clíticos, Echenique (1981) ha estudiado también la evolución histórica del leísmo, y apunta que la confusión de los pronombres personales átonos es un rasǵo típico del castellano, que lo caracteriza frente a las demás lenguas románicas, cuyos hablantes no vacilan en el uso de sus pronombres. Respecto a la evolución de este fenómeno, afirma que el leísmo de complemento directo personal masculino se desarrolló en el siǵlo XII, extendiéndose a principios de la segunda mitad del siǵlo XIII. A partir de 1283, sigue argumentando, cedieron las formas apocopadas, quizá por el rechazo hacia las mismas de Alfonso X, lo que benefició el desarrollo 
del uso de los pronombres lo y le, aunque bajo las formas apocopadas subsistió la oposición entre le (complemento indirecto) y lo (complemento directo). El leísmo personal singular mostraba la tendencia a esbozar un paradiǵma le / la / lo, similar al de este / esta / esto, por lo que, al no existir un pronombre neutro al que oponer el masculino, el leísmo en plural se empleaba en menor medida. Durante los siǵlos XIII y XIV, surǵieron muestras sueltas de leísmo de cosa que se incrementaron notablemente en el siglo XV, siendo los siglos XVI y XVII el momento culminante del leísmo masculino, leísmo que no establece diferencias entre persona y cosa. Por otro lado, el leísmo de persona femenino no es tan habitual. Con referencia al laísmo, Echenique (1981) sitúa su origen con posterioridad al nacimiento del leísmo, ya que los primeros ejemplos de esta variación se recogen en textos del siǵlo XIV, siendo en el XV cuando se empieza a extender. Por último, también de acuerdo con Echenique (1981), el loísmo es incluso anterior a ambos, ya que contamos con ejemplos de su existencia en el Poema de Mío Cid (siǵlo XII) y en la obra de Gonzalo de Berceo (siǵlo XIII).

Con la llegada del siǵlo XVIII, asistimos al inicio del español moderno y la estandarización de la gramática por parte de la Real Academia de la Lengua. Es a partir de entonces cuando aumenta la distancia entre el español escrito y el hablado, ya que los escritores se ven compelidos a seguir las reǵlas dictadas por la Academia, mientras que la población general mantiene en la lengua hablada el uso habitual de los clíticos, que dependía en buena medida de las variaciones dialectales peninsulares.

Otra línea de investigación, que supone un cambio metodológico respecto a las investigaciones previas sobre el origen de las variaciones en los clíticos, es la que se desarrolla a partir de 1975 y tiene que ver con «las distinciones semánticas que el hablante introduce para transmitir exactamente su mensaje» (FernándezOrdoñez, 1993, p. 67). Fernández Ordoñez (2001) establece una evolución de los pronombres, cuyo origen fecha en la Edad Media, aunque «la abierta discusión que al respecto se documenta desde el siglo XVI parece simplemente sacar a la superficie lo que quizá era ya entes objeto de debate y controversia entre distintos castellano-hablantes» (p. 1). No obstante, como también apunta, responde en parte a la dialectología del castellano, ya que en Andalucía y en el País Vasco se aprecia una variación en el uso pronominal español; de hecho, esta misma investigadora afirma que «es necesario separar como un fenómeno independiente el leísmo por adstrato, producido por el contacto del español con lenguas que distinguen el género» (Fernández Ordóñez, 1993, p. 71). Por ello, ciertos gramáticos opinan que este uso no es totalmente incorrecto al responder, en el caso del castellano del País Vasco, al sustrato del vascuence, sustrato que es fácilmente observable en la serie de narraciones que se van a analizar, en las que se aprecia no solo esta, sino también otras muchas variaciones léxicas, fonéticas y sintácticas, con respecto a la lengua estándar. 
Siguiendo los parámetros formales y funcionales, no parece que vaya a resultar difícil distinguir cuándo nos hallamos ante una de las tres desviaciones, laísmo, leísmo y loísmo, sin embargó, hay ocasiones en que no resulta claro discernir si nos encontramos ante una de ellas, como por ejemplo sucede con los sustantivos de cosa cuyo contenido es un colectivo de personas, tales como «ciudad» o «ejército» (Uruburu Bidaurrazaga, 1993). Asimismo, otro tipo de leísmo problemático es el leísmo condicionado, que se produce por la concurrencia real o posible de otras funciones oracionales, o por otros mecanismos sintácticos. Uruburu Bidaurrazaǵa (1993) enumera las siguientes circunstancias que conducen a dicho tipo de leísmo:

- Sintagma preposicional con a: el uso de un sintaǵma preposicional con a en la función de complemento directo es el principal mecanismo productor de leísmo, ya que se igualan en el nivel del sintaǵma las estructuras de las funciones de complemento directo y complemento indirecto, igualación que se traslada a las formas pronominales. Para el autor, ésta es una de las explicaciones básicas sobre el origen del leísmo.

- Evolución de las construcciones latinas de doble acusativo en las que hay dos complementos, uno de cosa y otro de persona, del tipo «enviar algo a alguien»: en estas se genera una confusión de funciones si aparece solamente el sintaǵma «a alguien», que se toma como complemento directo debido a la preposición a.

- Evolución de las construcciones latinas de acusativo con complemento predicativo referido a él (que se pueden considerar como una variante del doble acusativo): en castellano se tiende a convertir el complemento predicativo en directo, el cual, más tarde, pasa a funcionar como indirecto. De esta forma, «lo hicieron director» evoluciona a «le hicieron director».

- Evolución de frases latinas con proposición de verbo en infinitivo: el sujeto de estas oraciones se declinaba en latín en acusativo, en su paso al castellano, el sujeto se interpretó como complemento directo, especialmente en los casos de verbos transitivos, y, más tarde, se interpretó como complemento indirecto, lo que dio lugar a leísmos.

- Presencia del se impersonal: en oraciones en las que convergen un complemento directo de persona y un se impersonal («se busca a Carlos»), se tiende a considerar el complemento directo como indirecto.

- Leísmo por la existencia de otros mecanismos sintácticos en la oración:

1. Elipsis: «agárrale a Juan» (la mano).

2. Equiparación de verbo con complemento directo con verbo sin complemento: «dar golpes» como «pegar».

3. Desdoblamiento funcional y semántico de un verbo en núcleo predicativo con complemento directo: «pegar» = «dar golpes» > «darlo golpes». 
Con relación al laísmo y loísmo, las variaciones no son tan importantes, pero Uruburu Bidaurrazaǵa (1993) afirma que aparecen en los siguientes casos:

- Uso de lo(s) y la(s) para complemento indirecto con referente de tercera persona.

- Uso de estos pronombres en la retención de formas herederas del acusativo latino, en estructuras que han sido reinterpretadas en castellano.

- Laísmo y loísmo de segunda persona para complemento directo en formas de cortesía.

- Uso de lo, la y sus plurales en función de complemento directo con verbos que en latín eran intransitivos y regían dativo y en su evolución al castellano pasaron a ser transitivos, tales como «obedecer», «gustar» $\mathrm{o}$ «apetecer», entre otros.

Atendiendo a estas explicaciones, se puede afirmar que no existe un solo motivo favorecedor del uso del laísmo, leísmo y loísmo, sino que concurren muchas razones, las cuales, además, tienden a funcionar conjuntamente en la mayoría de los casos. De acuerdo con Uruburu Bidaurrazaga (1993), se pueden destacar las siguientes causas catalizadoras:

- Formales: apócope, eufonía, atracciones de nos a los, asimilación del se, confusiones con los paradigmas de me, te, se y de este, esta, esto.

- Morfológicas: aplicación a estos pronombres de la oposición masculino / femenino / neutro, confusión de la forma usted / ustedes para la segunda persona, o paralelismo con el paradigma de me, te, se.

- Sintácticas: verbos de régimen dativo en latín, el uso de la preposición a para el complemento directo, o la presencia en una misma oración de un complemento regido por el verbo y un complemento directo, circunstancial o predicativo.

- Semánticas: oposiciones persona / no persona, persona / animal / cosa, determinado / indeterminado, etc.

También, estas desviaciones de la norma pueden aparecer por confusiones eventuales, economía lingüística y motivos sociológicos, como el uso regional por afianzamiento, o el prestigio que puede tener uno de los tres fenómenos en determinadas zonas geográficas. Asimismo, se debe tomar en consideración la variación dialectal, ya que diferentes dialectos llevan asociados diferentes usos de los pronombres clíticos.

De acuerdo con Alcina y Blecua (1975), hoy en día estos tres fenómenos son recurrentes en el habla de la población, aunque no tienen la misma consideración por parte de los hablantes. Así, el leísmo de persona aparece muy extendido y tiene cierta nota de prestigio, debido al hecho de que lo utilizan hablantes cultos e irradia de Madrid. En cambio, el leísmo de cosa carece de esta consideración y se aprecia una disminución en su uso. El laísmo, por su parte, es más propio de la lengua hablada y, debido al hecho de que se usa en situaciones informales, su 
prestigio está disminuyendo. Por otro lado, se observa un retroceso en el uso del loísmo, variación que sufre un mayor rechazo, ya que la emplea un seǵmento de población con un acceso menor a la formación, generalmente en la lengua hablada, razón por la cual se evita totalmente en la lenǵua escrita.

\subsection{Variaciones, duplicaciones y omisiones de pronombres clíticos y el sustrato vascuence}

Para entender mejor la lengua utilizada en estos cuentos, debemos acercarnos previamente al vascuence o euskera ${ }^{4}$. Debido al sustrato vascuence, el castellano del País Vasco se ha visto influido por la lengua vasca, hasta el punto de que personas que no hablan euskera utilizan, sin ser conscientes de ello, un gran número de formas gramaticales, léxicas y fonéticas propias de esta lengua. Este hecho tiene su reflejo en los cuentos que se van a analizar, en los que el conjunto de los personajes es bilingüue y los que no lo son están rodeados de hablantes de euskera, debido a lo cual su castellano está muy influido por ésta lengua, influencia que se ve no solo en el uso de los pronombres átonos, sino también en otras formas lingüuísticas.

Son muchos los autores que se han centrado en la relación e influencias entre el castellano y el vascuence. Desde Alarcos, Alonso, Fernández Ramírez, Lapesa, Marcos Marín o Unamuno hasta Cano, Fernández Ulloa, Echenique, Korkostegii, Landa y Franco, Urrutia o Zárate entre otros muchos, se ha cubierto la historia de la convivencia en influjos entre ambas lenguas que, de acuerdo con Echenique (2016), «se manifiesta con claridad meridiana para un lingüuista en el orden gramatical (fonético-fonológico, morfológico y sintáctico), así como en el léxicosemántico» (p. 253). Y es este contacto entre lenguas el que podría «explicar (al menos en parte) las peculiaridades de los clíticos de 3.0 persona en el País Vasco en relación con otras variedades del español y otras lenguas romances» (Fernández Ulloa, 2006, p. 40), peculiaridades que son «por un lado, el leísmo para referentes animados masculinos y femeninos y, por otro, la posibilidad de omitir los pronombres con función de objeto directo con referentes definidos. [...] ambos fenómenos existen en el español general, solo que con mayores restricciones semánticas» (Camús y Gómez, 2015, p. 214), pero que, en el caso del País Vasco y norte de Navarra, debe buscarse su origen en «el contacto secular del español con el eusquera» (Fernández-Ordoñez, 1993, p. 73). Debido a lo explicado, a la lista de causas posibles de laísmo, leísmo y loísmo vistas con anterioridad, debemos añadir otra que, en este caso, resulta primordial y es el sustrato vasco de los hablantes.

\footnotetext{
4 De aquí en adelante, los términos vascuence y euskera se utilizarán indistintamente.
} 
La primera característica, que tiene incidencia en este tema y que distingue a ambas lenguas, es que en euskera no existe la distinción de género en el sustantivo. El morfema de articulo determinado /-a/ es común a todas las palabras y ni adjetivos ni sustantivos tienen ningún otro morfema que conlleve esta diferenciación, aunque existe una categoría que marca la distinción cosa / persona que «es muy importante ya que en euskera la declinación lo diferencia: etxera (a casa) / amarengana (a donde la madre) [en neǵrita en el original]» (Fernández Ulloa, 1997, p. 203). Los únicos elementos caracterizadores de género que posee el euskera son los morfemas /-k/ y /-n/ de los verbos, que solo se utilizan en la segunda persona del singular, de tal manera que se distingue entre «duk 2 pers. sing. masc. / dun 2 pers. sinǵ. fem. [en negrita en el oriǵinal]» (Fernández Ulloa, 1997, p. 203). Junto con esta, otra distinción de máxima relevancia es el hecho de que, mientras que el castellano cuenta con pronombres exentos con función de complemento directo e indirecto, en euskera ambos complementos se unen al lexema verbal por medio de sufijos. Por ello, no existen en vascuence los pronombres de tercera persona, salvo el de sujeto, y algunos demostrativos que se utilizan con función de sujetos, también en tercera persona.

Otra de las características que distinguen al euskera de las lenguas de su entorno es la relación entre el sistema verbal y los complementos oracionales, ya que la lengua vasca es ergativa. De esta manera, para referirse al complemento directo se usa el mismo pronombre que el de sujeto y, para formar el indirecto, se utiliza el pronombre de tercera persona declinado, al carecer de un pronombre propio para la función de complemento directo o indirecto. De acuerdo con Sagüués (2006), en euskera los pronombres átonos «son formas específicas, morfemas verbales, que van variando» (p. 51) y, sigue explicando, hay una serie de elementos que producen «variaciones en las formas verbales del euskera [...] que en castellano se corresponden al complemento directo y al complemento indirecto» (p. 51). Estos elementos, sigue arǵumentando, producen una distinción de cuatro tipos de verbos:

1. Verbos NOR: marcados por la influencia del sujeto y refieren una acción intransitiva.

2. Verbos NOR-NORI: marcados por la influencia del sujeto y del complemento indirecto y refieren quién realiza la acción intransitiva y respecto a quién se realiza.

3. Verbos NOR-NORK: influye la variación sujeto-complemento directo. Marcan quién hace la acción y el elemento sobre el que recae la misma.

4. Verbos NOR-NORI-NORK: inteǵran el sujeto, complemento directo y complemento indirecto. Marcan quién realiza la acción, ahora transitiva, el elemento sobre el que recae la acción y respecto a quién.

De tal manera que, según apunta Fernández-Ulloa (1997, p. 104), «en la frase verbal se da la triple concordancia de las estructuras verbales NOR/NORI/NORK, 
concordancia doble en caso de las estructuras NOR/NORK y NOR/NORI, que se opone a la concordancia verbal única de los verbos castellanos (que también aparece en euskera en las estructuras NOR)».

Como podemos observar, la estructura del verbo y del sintaǵma verbal es más compleja que la castellana, lengua que marca los complementos con pronombres exentos, como podemos ver en los siguientes ejemplos:

$\frac{\text { Me dio el juguete: }}{\text { CI }} \underset{\text { CD }}{\text { CI }} \frac{\text { lo dio }}{\text { CD }}$

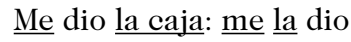

CI CD CI CD

Sin embargo, se han mantenido algunas formas en las que los complementos aparecen como morfemas verbales, formando una «unidad significativa» con el mismo (Alcina y Blecua, 1975, p. 609):

Trájomelo (arcaico)

Dámelo.

De acuerdo con Fernández Ulloa (1997, p. 204), la «múltiple concordancia contribuye a la enorme complejidad de la flexión verbal vasca y tiene consecuencias sintácticas» en el castellano del País Vasco, en nuestro caso, en el uso de los «pronombres átonos de tercera persona» (Cano-Aguilar, 1998, p. 30), que el euskera integra en el morfema verbal y para los que el castellano toma unidades léxicas. El leísmo, en relación con el vascuence, consistiría en la «anulación de los parámetros de caso y género en los pronombres átonos de tercera persona» (Camús y Gómez, 2015, p. 214). Estos mismos autores argumentan que el leísmo femenino, el cual «responde a los llamados cambios indirectos inducidos por contacto» (p. 214), viene dado por una «restructuración parcial del sistema pronominal átono con la anulación de los parámetros de caso [...] y de género, por tratarse de una categoría inexistente en la lengua vasca» (pp. 214-215). Fernández-Ordóñez (1993) sigue en la misma línea y expone que el empleo de los clíticos, por parte de los hablantes bilingües cuya primera lengua es el vascuence, se caracteriza por ser el pronombre le el único clítico empleado, con independencia de la posición sintáctica y el género del referente. La presencia de le se rige, no obstante, por dos normas:

- es obligatoria si el referente ha recibido caso dativo o si es animado (aunque el objeto reciba caso acusativo);

- si el referente es inanimado, los clíticos de acusativo se omiten con regularidad.

Fernández-Ordoñez (1993) añade un matiz al afirmar que este sistema se modifica ligeramente en los monolingüues en español de la región, de tal manera 
que le y les continúan actuando como pronombres de dativo y de acusativo para objetos animados, mientras que lo, los, la y las pueden emplearse como clíticos de acusativo para referirse a objetos inanimados.

Pero estas, sin embargo, no son las únicas variaciones que se observan con respecto al uso de los pronombres clíticos, ya que existen, también, otras dos modificaciones sintácticas que tienen las mismas causas arriba expuestas: la omisión del pronombre y su duplicación errónea.

Respecto a la omisión de los pronombres clíticos, Fernández Ordoñez (1993) explica que «los bilingües cuya lengua materna es el vascuence omiten regularmente los clíticos de acusativo salvo cuando el referente es animado, caso en que emplean exclusivamente le, les» (p. 76). En palabras de Camús y Gómez (2015), la omisión del pronombre clítico de objeto, al igual que el leísmo femenino, se debe también a «los llamados cambios indirectos inducidos por contacto» (p. 214), responde a factores sintácticos y semánticos y se manifiesta de manera asistemática, debido al hecho de que existe la «posibilidad de omisión con referentes definidos y, en ciertos contextos, animados, lo que responde a las características del verbo vasco que integra en su forma auxiliar los objetos de los verbos» (Camús y Gómez, 2015, p. 215). Echenique (1981) aduce motivos sintácticos para esta omisión, lo mismo que Zárate, que pone en relación el vascuence con el guaraní y el quechua, al explicar que, en las tres lenguas, los clíticos de objeto se integran como morfemas de la raíz verbal (1976). Respecto a la relación entre lenguas, MendietaLombardo y Molina (1995, p. 32) afirman que la supresión del clítico «está relacionada directamente con el grado de bilingüismo de modo que, cuanto mayor es el contacto con el euskera, mayores son las probabilidades de que aparezca».

Por otro lado, la duplicación pronominal o redundancia pronominal se define como la «coaparición de un clítico junto a su variante tónica o junto al grupo nominal al que se refiere, que se encuentra, además, pospuesto al verbo» (Camús y Gómez, 2015, p. 216). Esta variación lingüuística se registra en mayor medida con antecedentes humanos, tanto masculinos como femeninos, específicos y definidos.

A modo de resumen, Fernández-Ordóñez presenta una tabla con el uso de los pronombres clíticos en el castellano hablado en el País Vasco:

Sistema del romance en contacto con el vascuence

$\begin{array}{ccccc}\text { Acusativo } & \text { Animados } & \text { Inanimados } & \text { Neutro } \\ & \text { le(s) } & \text { Masculino } & \text { Femenino } & \emptyset / \text { lo } \\ \text { Dativo } & \operatorname{le}(\mathrm{s}) & \emptyset / \mathrm{lo}(\mathrm{s}) & \emptyset / \mathrm{la}(\mathrm{s}) & \mathrm{le}\end{array}$

Fuente: Fernández-Ordóñez (2001, p. 14). 


\section{Corpus analizado y análisis lingüuístico}

El corpus que se va a analizar se ha extraído de una serie de relatos breves escritos durante el primer tercio del siglo XX por cuatro autores vizcaínos, en los que se reflejan diálogos que muestran el habla de los habitantes del área de la villa de Bilbao, especialmente de las zonas rurales aledañas a la capital. A día de hoy, la topografía de la zona ha cambiado, ya que, por ejemplo, en uno de los relatos estudiados se habla de Deusto como pueblo próximo a la capital, población que el 1 de enero de 1925 se anexionó como barrio a la misma ${ }^{5}$.

Según refiere Urrutia Cárdena (2003),

aunque los testimonios literarios diacrónicos no nos permiten establecer la situación inicial, las muestras de uso oral de informantes bilingües contemporáneos con escaso dominio del castellano nos permiten vislumbrar el manejo dificultoso de los clíticos de $3^{\text {a }}$ persona por los hablantes vascófonos en su aprehensión del romance (pp. 521-522).

Sin embargó, no debemos olvidar que, en palabras de Juaristi, «el alegado dialecto -o mal castellano de los vascos- es un recurso o jerga literaria y convencional como el sayagués de las comedias» (Líbano Zumalacárregui, 1997, p. 129). Por ello, difícilmente podremos extraer conclusiones generalizadoras sobre el uso de los pronombres, sino mostrar la caracterización sincrónica que varios literatos hacen del castellano hablado por bilingües cuya lengua materna es el euskera.

\subsection{Autores}

Juan Arzadun ${ }^{6}$ (Bermeo 1862-1950) fue militar de carrera, político y poeta. En su carrera profesional obtuvo los cargos de gobernador civil y militar de Gipuzkoa, llegando a ser general y director de la Academia de Artillería, hasta que Primo de Rivera lo depuso por su oposición a la dictadura. En 1924, el rey Jorge V de Inǵlaterra le nombró Caballero del Imperio británico. En su faceta de escritor perteneció a la generación del 98, publicando dramas, narraciones y cuadros literarios centrados en el País Vasco. Unamuno, gran amigo suyo, redactó el prólogo de Poesías de Juan de Arzadun en 1897. De este autor se analiza la obra Cuentos vascos (Bilbao, 1921).

Juan de Irigoyen Guerricabeitia ${ }^{7}$, abogado que nació y falleció en Bergara (1884-1964), fue un gran aficionado a la pelota vasca, llegando a participar en los

5 http://www.bilbaopedia.info/anexion-deusto

6 http://aunamendi.eusko-ikaskuntza.eus/eu/arzadun-zabala-juan-de/ar-14979/

7 http://aunamendi.eusko-ikaskuntza.eus/eu/irigoyen-juan-de/ar-69917/ 
campeonatos vascos de los años 1915, 1917 y 1918. Entre sus obras destacan $E l$ juego de pelota a mano, 1900-1925 (1926), Los tremendos de Kanala, Kresala eta Lurruna (1936), El «Cho» del Carmengo Amam (1938) o Magde, la capitanesa (1961), además de otras publicaciones relacionadas con el mundo marinero y de la pesca. De este autor se analiza la obra Los tremendos de Kamala (Bilbao, 1936).

Manuel Aranaz Castellanos ${ }^{8}$ (La Habana, 1875-Bilbao, 1925) fue un escritor de origen vasco que estudió en la Universidad de Deusto, aunque trabajó como periodista. Tras su paso por la dirección de El Liberal de Bilbao, llegó a ser presidente del Colegio de Corredores de Comercio de Bilbao y, posteriormente, del Círculo de Bellas Artes. Fue autor de narraciones y obras de teatro, una de las cuales se estrenó en la capital vizcaína, aunque no podamos hablar de una producción literaria de calidad. De este autor se analiza la obra Cuadros vascos (Bilbao, 1969).

Rafael Sánchez Matas (Madrid 1894-1966). De acuerdo con Saiz Valdivieso (2010), tras la muerte de su padre el mismo año de su nacimiento, su madre decidió volver a su Bilbao natal, donde su hijo se crio y educó. En esa ciudad empezó su andadura literaria, centrada en colaboraciones con revistas y periódicos tales como el $A B C$. En 1933 se incorporó a la junta directiva de la recién fundada Falange Española. Llegó a ser ministro sin cartera y le fue concedido un sillón en la Academia de la Lengua. Padre del también escritor Rafael Sánchez Ferlosio. De este autor se analiza la obra La vida nueva de Pedrito de Andía (Madrid, 1968).

\subsection{Corpus}

Transcribimos aquí todas las oraciones en las que aparecen pronombres clíticos de tercera persona. Hemos dispuesto las mismas en la primera columna de una tabla para, a continuación, analizarlas en la segunda columna y nombrar la tipología de variaciones de la norma en la tercera. No hemos realizado ninguna referencia a las obras en las que aparecen las frases, porque nuestro fin es el estudio del hecho linguuístico en sí, de manera cuantitativa, con independencia de su origen.

Partimos de la afirmación de que «en el País Vasco es general el leísmo de persona masculina, pero también el de persona femenina» (Fernández Ulloa, 1997, p. 203).

8 http://aunamendi.eusko-ikaskuntza.eus/eu/aranaz-castellanos-manuel/ar-2143/ 


\begin{tabular}{|c|c|c|c|}
\hline & Frase & $\begin{array}{l}\text { Pronombre clítico/ } \\
\text { función }\end{array}$ & Variación sintáctica \\
\hline 1 & «aquí traigo (la carta)» & - & $\begin{array}{l}\text { SUPRESIÓN DEL } \\
\text { PRONOMBRE LA }\end{array}$ \\
\hline 2 & «leyó en voz alta (la carta)» & - & $\begin{array}{l}\text { SUPRESIÓN DEL } \\
\text { PRONOMBRE LA }\end{array}$ \\
\hline 3 & «ya os daré (el caserío)» & - & $\begin{array}{l}\text { SUPRESIÓN DEL } \\
\text { PRONOMBRE LO }\end{array}$ \\
\hline 4 & $\begin{array}{l}\text { «ya sabes que a tu padre le tengo en las } \\
\text { rentas» }\end{array}$ & le - C.D. & DUPLICACIÓN \\
\hline 5 & «sin dar(le) tiempo a Mari Carmen» & - & $\begin{array}{l}\text { SUPRESIÓN DEL } \\
\text { PRONOMBRE LE }\end{array}$ \\
\hline 6 & «cuando el mozo (le) preguntó a la neska» & - & $\begin{array}{l}\text { SUPRESIÓN DEL } \\
\text { PRONOMBRE LE }\end{array}$ \\
\hline 7 & «que podía aparecerle ente él golosa» & le & DUPLICACIÓN \\
\hline 8 & $\begin{array}{l}\text { «no era el amor burlado lo que le dolía, era el } \\
\text { temor a que la creyeran cómplice» }\end{array}$ & $\begin{array}{l}\text { le - C.I. } \\
\text { la - C.D. }\end{array}$ & $\begin{array}{l}\text { LAÍSMO } \\
\text { DOBLE ACUSATIVO }\end{array}$ \\
\hline 9 & «la señora le abrazaba cariñosamente (a ella)» & le - C.D. & LEÍSMO \\
\hline 10 & «dame la carta para que te la lea» & la - C.D. & - \\
\hline 11 & «no le hizo ni pizca de ǵracia» & le - C.I. & - \\
\hline 12 & «ya le he dicho a la tía que» & le - C.I. & DUPLICACIÓN \\
\hline 13 & «un color se le iba y otro se le venía» & le - C.I. & - \\
\hline 14 & «ya lo sabes chiquilla, yo te quiero» & lo - C.D. & DUPLICACIÓN \\
\hline 15 & «allí se la sintió lavar vasos» & la - C.I. & LAISMO \\
\hline 16 & «la señora le abrazaba cariñosamente (a ella)» & le - C.D. & LEÍSMO \\
\hline 17 & «no hay aldeano a quien le parezca mal» & le - C.I. & - \\
\hline 18 & $\begin{array}{l}\text { «eso no lo daba la tierra y sólo podía hacerlo } \\
\text { él» }\end{array}$ & lo - C.D. & - \\
\hline 19 & «enǵañar, también, ya le harás» & le - C.I. & - \\
\hline 20 & «con decir que le palpitaba el corazón» & le - C.I. & - \\
\hline 21 & «que un grillo vale dos cuartos y se le oye» & le - C.I. & - \\
\hline 22 & $\begin{array}{l}\text { «el galán sintió un frío que le recorrió por } \\
\text { la espalda, y el dolor...le produjo, le hizo } \\
\text { comprender cuanto quería a aquella» }\end{array}$ & $\begin{array}{l}\text { le (recorrió) - C.D. } \\
\text { le (produjo) - C.I } \\
\text { le (hizo) - C.I. }\end{array}$ & $\begin{array}{l}\text { LEÍSMO } \\
- \\
-\end{array}$ \\
\hline 23 & «le pareció que así le creería mejor» & $\begin{array}{l}\text { le (pareció) - C.I. } \\
\text { le (creería) - C.D. }\end{array}$ & - LEÍSMO. \\
\hline 24 & «que le había ofendido tanto (a ella)» & le - C.D. & LEÍSMO \\
\hline
\end{tabular}




\begin{tabular}{|c|c|c|c|}
\hline & Frase & $\begin{array}{l}\text { Pronombre clítico/ } \\
\text { función }\end{array}$ & Variación sintáctica \\
\hline 25 & $\begin{array}{l}\text { «luego le recordó sus proyectos de honrado } \\
\text { trabajo (a ella)» }\end{array}$ & le - C.I. & - \\
\hline 26 & $\begin{array}{l}\text { «le pedía (a ella) que no le recordase con } \\
\text { rencor» }\end{array}$ & le - C.D. & LEÍSMO \\
\hline 27 & $\begin{array}{l}\text { «aquella gente que no le entendía, ni le } \\
\text { comprendía a él» }\end{array}$ & $\begin{array}{l}\text { le (entendía) - C.D. } \\
\text { le (comprendía) - } \\
\text { C.D. } \\
\text { a él }\end{array}$ & $\begin{array}{l}\text { LEÍSMO } \\
\text { LEÍSMO Y } \\
\text { DUPLICACIÓN }\end{array}$ \\
\hline 28 & «mirándole (a él) cara a cara» & le - C.D. & LEÍSMO \\
\hline 29 & $\begin{array}{l}\text { «no le quedaba tiempo (a la naturaleza) para } \\
\text { arrullar a sus hijos» }\end{array}$ & le - C.I & - \\
\hline 30 & «aquellos la cantan... (la vida)» & la - C.D. & - \\
\hline 31 & $\begin{array}{l}\text { «consentía en que el bodorrio se lo llevase la } \\
\text { trampa» }\end{array}$ & lo - C.D. & DUPLICACIÓN \\
\hline 32 & «más bien que tacaña, la creía tozuda (a ella)» & la - C.D. & \\
\hline 33 & $\begin{array}{l}\text { «todos, admirando su fácil palabra, le oían } \\
\text { como un oráculo, le habían lisonjeado» }\end{array}$ & $\begin{array}{l}\text { le (oían) - C.D. } \\
\text { le (habían } \\
\text { lisonjeado) - C.D. }\end{array}$ & $\begin{array}{l}\text { LEÍSMO } \\
\text { LEÍSMO }\end{array}$ \\
\hline 34 & $\begin{array}{l}\text { «a quienes (les) sería fácil...les deslumbraba } \\
\text { (a ellos)» }\end{array}$ & $\begin{array}{l}\text { (les) sería } \\
\text { les - C.D. }\end{array}$ & $\begin{array}{l}\text { OMISIÓN DEL PRONOMBRE } \\
\text { LES. } \\
\text { LEÍSMO }\end{array}$ \\
\hline 35 & $\begin{array}{l}\text { «andando el tiempo le irritó la obstinación } \\
\text { que ponían a su elocuencia» }\end{array}$ & le - C.D. & LEÍSMO \\
\hline 36 & $\begin{array}{l}\text { «sin lograr otra cosa que coronarla (a ella) de } \\
\text { espumarajos impotentes» }\end{array}$ & $\begin{array}{l}\text { la - C.D. } \\
\text { Recurrencia de } \\
\text { complemento } \\
\text { de rección } \\
\text { preposicional y C.D. }\end{array}$ & - \\
\hline 37 & «también ellos le miraban (a él) con recelo» & le - C.D. & LEÍSMO \\
\hline 38 & «les hacía ver (a ellos) en él al comediante» & les - C.I. & - \\
\hline 39 & «se resolvió, mohíno, a deshacer lo hecho» & lo - C.D. & - \\
\hline 40 & «el mozo le explicó su artimaña (a ella)» & le - C.I. & - \\
\hline 41 & «que si fueran preǵuntados, os lo verificarán» & lo - C.D. & - \\
\hline 42 & $\begin{array}{l}\text { «a nadie se le ocurría poner tacha al } \\
\text { testimonio» }\end{array}$ & le - C.I. & - \\
\hline 43 & «si alǵuien lo requiere» & lo-C.D. & - \\
\hline 44 & $\begin{array}{l}\text { «cita en el juicio a un hombre que, según ella, } \\
\text { le ha roto el brazo» }\end{array}$ & le - C.I & - \\
\hline
\end{tabular}




\begin{tabular}{|c|c|c|c|}
\hline & Frase & $\begin{array}{l}\text { Pronombre clítico/ } \\
\text { función }\end{array}$ & Variación sintáctica \\
\hline 45 & $\begin{array}{l}\text { «un perrazo negro se le metió (a él) entre las } \\
\text { piernas» }\end{array}$ & le - C.D. & - \\
\hline 46 & $\begin{array}{l}\text { «él, encolerizado, le arrojó una piedra y el } \\
\text { perrazo huyó» }\end{array}$ & le - C.I. & - \\
\hline 47 & $\begin{array}{l}\text { «si ella lo reconocía así, él estaba dispuesto } \\
\text { a pagar»» }\end{array}$ & lo - C.D. & - \\
\hline 48 & $\begin{array}{l}\text { «por huir de la gente que (a ella) le quiere } \\
\text { mal» }\end{array}$ & le - C.D. & LEÍSMO \\
\hline 49 & «el borracho la apedrea y la hiere» & $\begin{array}{l}\text { la (apedrea) - C.D. } \\
\text { la (hiere) - C.D. }\end{array}$ & - \\
\hline 50 & «ahí tienes al vecino, como le trae una bruja» & le - C.D. & LEÍSMO \\
\hline 51 & «¿a que no le aciertas el mal a ese pobre?» & le - C.I. & - \\
\hline 52 & $\begin{array}{l}\text { «los que le cuidaban (a él) refirieron al } \\
\text { médico» }\end{array}$ & le - C.D. & LEÍSMO \\
\hline 53 & $\begin{array}{l}\text { «aquel mal traidor que le acometía en plena } \\
\text { robustez, incapacitándole para ir al mar» }\end{array}$ & $\begin{array}{l}\text { le (acometía) - C.D. } \\
\text { (incapacitando)le- } \\
\text { C.D. }\end{array}$ & $\begin{array}{l}\text { LEÍSMO } \\
\text { LEÍSMO }\end{array}$ \\
\hline 54 & $\begin{array}{l}\text { «la idea de averiguar quién era la que le } \\
\text { perseguía se fijó en su mente» }\end{array}$ & le - C.D. & LEÍSMO \\
\hline 55 & «no le dejaban (a ella) los mamarros» & le - C.D. & LEÍSMO \\
\hline 56 & «una ves le encontré (a ella) y al río iba» & le - C.D. & LEÍSMO \\
\hline 57 & $\begin{array}{l}\text { «en la heredad a las "dose" de la noche topar } \\
\text { le «hiso» (a ella)» }\end{array}$ & $\begin{array}{l}\text { le - C.I. por la } \\
\text { forma, ya que } \\
\text { semánticamente } \\
\text { sería un C.D., por lo } \\
\text { tanto sería Leísmo. }\end{array}$ & LEÍSMO \\
\hline 58 & $\begin{array}{l}\text { «al encontrarla (a ella) en su camino, el } \\
\text { enfermo sintió» }\end{array}$ & la - C.D. & - \\
\hline 59 & $\begin{array}{l}\text { «¡aquella era la razón que le atormentaba y } \\
\text { perseguía (a él)!» }\end{array}$ & le - C.D. & LEÍSMO \\
\hline 60 & «la sibila le anunció (a él) que sufría» & le - C.I. & - \\
\hline 61 & $\begin{array}{l}\text { «para romper el conjuro le recomendó } \\
\text { diferentes prácticas» }\end{array}$ & le - C.I. & - \\
\hline 62 & $\begin{array}{l}\text { «la persona que se le apareciera al rompérsele } \\
\text { el cacharro sería infaliblemente la hechicera» }\end{array}$ & le - C.I. & - \\
\hline 63 & $\begin{array}{l}\text { «en aquella inquietud que le imponían los } \\
\text { mamarros (a ella)» }\end{array}$ & le - C.I. & - \\
\hline 64 & $\begin{array}{l}\text { «desde entonces, al encontrarle, la bruja } \\
\text { sonreía» }\end{array}$ & le - C.D. & LEÍSMO \\
\hline
\end{tabular}




\begin{tabular}{|c|c|c|c|}
\hline & Frase & $\begin{array}{l}\text { Pronombre clítico/ } \\
\text { función }\end{array}$ & Variación sintáctica \\
\hline 65 & «estrechaba el cerco y le rondaba (a él)» & le - C.D. & LEÍSMO \\
\hline 66 & «le siguió (a él) el médico» & le - C.D. & LEÍSMO \\
\hline 67 & $\begin{array}{l}\text { «se decidió a hacer frente a la jauría que le } \\
\text { acosaba (a él)» }\end{array}$ & le - C.D. & LEÍSMO \\
\hline 68 & «le increpó a la vieja» & le & DUPLICACIÓN \\
\hline 69 & $\begin{array}{l}\text { «¿qué le había hecho él (a ella) para que le } \\
\text { persiǵuiera así?» }\end{array}$ & $\begin{array}{l}\text { le (había hecho) - } \\
\text { C. I. } \\
\text { le (persiguiera) - } \\
\text { C.D. }\end{array}$ & LEÍSMO \\
\hline 70 & $\begin{array}{l}\text { "¿por qué venganza implacable le torturaba... } \\
\text { enviándole aquellos espíritus atormentadores } \\
\text { que le apretaban la garganta?» }\end{array}$ & $\begin{array}{l}\text { le (torturaba) - C.D. } \\
\text { (enviando)le - C.I. } \\
\text { le (apretaban) - C.I. }\end{array}$ & $\begin{array}{l}\text { LEÍSMO } \\
- \\
-\end{array}$ \\
\hline 71 & «resuelto a hacerlos (los sufrimientos) cesar» & los - C.D. & - \\
\hline 72 & «la bruja... le exhortaba sonriente (a él)» & le - C.D. & LEÍSMO \\
\hline 73 & «como si le (a ella) divirtiera la escena» & le - C.I. & - \\
\hline 74 & $\begin{array}{l}\text { «sentía que le empezaban a pasar...visiones } \\
\text { rojas» }\end{array}$ & le - C.I. & - \\
\hline 75 & $\begin{array}{l}\text { «por buenas que le diǵa a ver si me deja (a } \\
\text { él)» }\end{array}$ & le - C.I. & - \\
\hline 76 & $\begin{array}{l}\text { «lodo aquel drama de la superstición..., le } \\
\text { conturbaba (a él)» }\end{array}$ & le - C.D. & LEÍSMO \\
\hline 77 & $\begin{array}{l}\text { "y entre verse obligado a servir a un bando } \\
\text { que nada le decía» }\end{array}$ & le - C.I. & - \\
\hline 78 & «ni él las necesitaba (las razones) aquí» & las - C.D. & - \\
\hline 79 & $\begin{array}{l}\text { «él se vio en una situación...que le tenía } \\
\text { desorientado» }\end{array}$ & le - C.I. & - \\
\hline 80 & $\begin{array}{l}\text { «en asuntos que ni entendía ni le } \\
\text { interesaban» }\end{array}$ & le - C.I. & - \\
\hline 81 & «la vida del caserío le era extraña» & le - C.I. & - \\
\hline 82 & «la comida del ganado la hacía la vieja madre» & la-C.D. & DUPLICACIÓN \\
\hline 83 & $\begin{array}{l}\text { «el gobierno...lo hacían entre la etxekoandre } \\
\text { y un morroi» }\end{array}$ & lo - C.D. & DUPLICACIÓN \\
\hline 84 & $\begin{array}{l}\text { «como para que Mortero lo estimara } \\
\text { merecedor de» }\end{array}$ & lo - C.D. & - \\
\hline 85 & $\begin{array}{l}\text { «y aunque no le merecían ǵran estima (los } \\
\text { convecinos)» }\end{array}$ & le - C.I. & - \\
\hline 86 & «le dolía la preponderancia de la mujer» & le - C.I. & - \\
\hline
\end{tabular}




\begin{tabular}{|c|c|c|c|}
\hline & Frase & $\begin{array}{l}\text { Pronombre clítico/ } \\
\text { función }\end{array}$ & Variación sintáctica \\
\hline 87 & $\begin{array}{l}\text { «"el hombre no puede llegar a menos", le } \\
\text { decía a su amigo» }\end{array}$ & le - C.I. & - \\
\hline 88 & «el trabajo lo realizaba con fiebre» & lo - C.D. & DUPLICACIÓN \\
\hline 89 & «para asarlo sobre la chapa y briznarlo lueǵo» & $\begin{array}{l}\text { (asar)lo - C.D. } \\
\text { (briznar)lo - C.D. }\end{array}$ & - \\
\hline 90 & $\begin{array}{l}\text { «que se reservó para cuando lo hicieran ellos } \\
\text { famoso (el nombre)» }\end{array}$ & lo - C.D. & - \\
\hline 91 & $\begin{array}{l}\text { «ganas de lucir Mastraga, conocimientos } \\
\text { ortográficos que se le reconocían» }\end{array}$ & le - C.I. & - \\
\hline 92 & $\begin{array}{l}\text { «cierto terror a las complicaciones } \\
\text { ortográficas... les hizo allanarse por ésta vez» }\end{array}$ & les - C.I. & - \\
\hline 93 & «Mastraga lo juǵaba (el tresillo)» & lo - C.D. & - \\
\hline 94 & $\begin{array}{l}\text { «(a Mastraǵa) le inició y adiestró en el jueǵo el } \\
\text { cura párroco» }\end{array}$ & le - C.D. & LEÍSMO \\
\hline 95 & $\begin{array}{l}\text { «Mastraga le recordaba (al cura) en lodos los } \\
\text { incidentes del jueǵo» }\end{array}$ & le - C.D. & LEÍSMO \\
\hline 96 & $\begin{array}{l}\text { «asignatura que se la traían bien aprendida } \\
\text { los curas de antes» }\end{array}$ & la - C.D. & - \\
\hline 97 & $\begin{array}{l}\text { «de aquella época... le quedaba un refranero } \\
\text { latino» }\end{array}$ & le - C.I. & - \\
\hline 98 & $\begin{array}{l}\text { «la fama de hombre letrado que le adjudicaba } \\
\text { a Mastraǵa la gente» }\end{array}$ & le - C.I. & DUPLICACIÓN \\
\hline 99 & $\begin{array}{l}\text { «convirtiéndole en un barbarote... al que no le } \\
\text { quedaban más habilidades» }\end{array}$ & $\begin{array}{l}\text { (convirtiendo)le - } \\
\text { C.D. } \\
\text { le (quedaban) - C.I. }\end{array}$ & LEÍSMO \\
\hline 100 & $\begin{array}{l}\text { «y no por los latines que se le revolvían en la } \\
\text { locuacidad» }\end{array}$ & le - C.I. & - \\
\hline 101 & $\begin{array}{l}\text { «en las que aducía su alta calidad de } \\
\text { intelectual que se la otorgaban sus dos } \\
\text { consocios, pensando utilizarla cuando } \\
\text { prosperasen los negocios» }\end{array}$ & $\begin{array}{l}\text { la (otorgaban) - C.D. } \\
\text { (utilizar)la - C.D. }\end{array}$ & - \\
\hline 102 & «pero no se le alcanzaba(a Mortero) la forma» & le - C.I. & - \\
\hline 103 & $\begin{array}{l}\text { «alterar...aquel régimen ya establecido le } \\
\text { parecía al disminuido (Mortero) empresa } \\
\text { inalcanzable» }\end{array}$ & le - C.I. & DUPLICACIÓN \\
\hline 104 & $\begin{array}{l}\text { «y podía aleccionarle (a Mortero) con el } \\
\text { ejemplo de lo ocurrido» }\end{array}$ & le - C.D. & LEÍSMO \\
\hline 105 & $\begin{array}{l}\text { «ni mentar que soy su padre le han hecho } \\
\text { nunca» }\end{array}$ & le - C.I. & - \\
\hline
\end{tabular}




\begin{tabular}{|c|c|c|c|}
\hline & Frase & $\begin{array}{l}\text { Pronombre clítico/ } \\
\text { función }\end{array}$ & Variación sintáctica \\
\hline 106 & «yo no me atrevo ni a reñirle (al hijo)» & le - C.D. & LEÍSMO \\
\hline 107 & «porque asustó a...le peǵué un txalo» & le - C.I. & - \\
\hline 108 & «a verlo» & lo - C.D. & - \\
\hline 109 & «eso... ni mentarlo (el dinero)» & lo - C.D. & - \\
\hline 110 & «si no (lo) haces ahora» & & $\begin{array}{l}\text { SUPRESIÓN DEL } \\
\text { PRONOMBRE LO }\end{array}$ \\
\hline 111 & $\begin{array}{l}\text { «él se dio cuenta de la gravedad del paso que } \\
\text { le indicaba su amigo...y se propuso darlo el } \\
\text { mismo día» }\end{array}$ & $\begin{array}{l}\text { le (indicaba) - C.I. } \\
\text { (dar)lo - C.D. }\end{array}$ & - \\
\hline 112 & $\begin{array}{l}\text { «él abordó a su mujer anunciándole que } \\
\text { quería» }\end{array}$ & le - C.I. & - \\
\hline 113 & «y esto había de decidirlo en el día» & lo- C.D. & DUPLICACIÓN \\
\hline 114 & «eso es para hablar(lo) con todos en casa» & & $\begin{array}{l}\text { SUPRESIÓN DEL } \\
\text { PRONOMBRE LO }\end{array}$ \\
\hline 115 & «no me vuelvo de nada de lo dicho» & lo- C.D. & - \\
\hline 116 & «el morroi llamó a la vieja y le puso en autos» & le - C.D. & LEÍSMO \\
\hline 117 & $\begin{array}{l}\text { "proponía la guerra en los mismos términos } \\
\text { que la planteaba él» }\end{array}$ & la - C.D. & - \\
\hline 118 & $\begin{array}{l}\text { "pero el hijo, capaz de llevar(selo) como ha } \\
\text { dicho» }\end{array}$ & & $\begin{array}{l}\text { SUPRESIÓN DEL } \\
\text { PRONOMBRE LO }\end{array}$ \\
\hline 119 & $\begin{array}{l}\text { "como le he dicho a esta...tenemos que } \\
\text { arreǵlar lo de la casa» }\end{array}$ & le - C.I. & DUPLICACIÓN \\
\hline 120 & «a la etxekoandre casi se le pasó el susto» & le - C.I. & DUPLICACIÓN \\
\hline 121 & $\begin{array}{l}\text { «que venga (el chico) a Busturia...y ya le } \\
\text { saldremos con el bote» }\end{array}$ & le - C.I. & - \\
\hline 122 & $\begin{array}{l}\text { «algún proyecto de obra de reforma de la } \\
\text { cocina para la que tenía» }\end{array}$ & la - C.D. & - \\
\hline 123 & $\begin{array}{l}\text { «Mortero lo iba arreǵlando todo sobre la } \\
\text { marcha» }\end{array}$ & lo-C.D. & DUPLICACIÓN \\
\hline 124 & $\begin{array}{l}\text { «su mujer le cepilló la ropa (a Mortero), le dio } \\
\text { el pañuelo...le despidió con una sonrisa...le } \\
\text { acompañó...mientras le recordaba ¿ya llevas } \\
\text { perras para la bandeja?» }\end{array}$ & $\begin{array}{l}\text { le (cepilló)- C.I. } \\
\text { le (dio) - C.I. } \\
\text { le (despidió) - C.D. } \\
\text { le (acompañó) - } \\
\text { C.D. } \\
\text { le (recordaba) - C.I. }\end{array}$ & $\begin{array}{l}- \\
- \\
\text { LEÍSMO } \\
- \\
\text { LEÍSMO }\end{array}$ \\
\hline
\end{tabular}


125 «no la pareció al notable diplomático muy de fiar la mansa actitud de la mujer y, así, le comunicó a éste sus dudas»

126 «no le gustó a Mortero el tono impertinente de su mentor»

127 «el coche-remolque, descansando de la media le-C.D. tonelada con que acaban de aligerarle»

128 «Visente y sus amigos luego de contemplarlo lo - C.D. (el tranvía)»

129 «volviéndose a sus amigotes que le siǵuen (a él)» le - C.D.

130 «un cachorrillo de caza...les sale al encuentro y les lame las manos (a ellos)»

131 «los amiǵos le siǵuen (a Vicente)»

132 «la parroquia de Deusto elévase del montón la-C.D. de viviendas que la rodea»

133 «los amigos le imitan (a él) sonrientes» le - C.D.

LEISMO

134 «uno de ellos...deja caer hasta su fondo (del lo - C.D. pozo) el cubo, lo eleva después»

135 «nosotros solos (lo) prepararemos» le (pareció) - C.I.

(comunicó) - C.I. DUPLICACIÓN le (comunicó a éste)

DUPLICACIÓN

LEÍSMO les (sale) - C.I les (lame) - C.I.

LEÍSMO

le - C.D. LEÍSMO

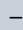

SUPRESIÓN DEL PRONOMBRE LO

136 «que Visente se prepare para darle vueltas al DUPLICACIÓN chisme»

137 «secando el sudor que les escurre por las les - C.I. frentes»

138 «tropieza con el inquilino del caserío y le le - C.I. tiende el cucharón»

139 «el aldeano...hace un gesto de inteligencia, (enmienda)lo - C.D. enmiéndalo después por la consideración a la le (invita) - C.D. LEÍSMO cara feliz y satisfecha de quien le invita»

140 «los días de... los gasta (los cigarros) de esa los - C.D. clase»

141 «nadie lo hubiese dicho (que iba a ser un día lo - C.D. de mucha calor)»

142 «tomé el chocolate, me (lo) habían dejado SUPRESIÓN DEL preparadito» PRONOMBRE LO

143 «recién ordeñada (la) tomaremos (la leche)» SUPRESIÓN DEL PRONOMBRE LA

144 «la beberán (la leche) ahí fuera»

la - C.D 
145 «ellos le convencen (a él) de que sería una cochinada» dudoso:

si le es C.D. sería

LEÍSMO y además

tendríamos en la

misma oración C.D.

y C.R.P, que según

alğunos gramáticos son incompatibles; por ello, estos se inclinan a hablar en estos casos de C.I.

\begin{tabular}{|c|c|c|c|}
\hline 146 & «he tenido que cocer(la)» & & $\begin{array}{l}\text { SUPRESIÓN DEL } \\
\text { PRONOMBRE LA }\end{array}$ \\
\hline 147 & «se la ha terminado toda (la leche)» & la - C.D. & - \\
\hline 148 & «y mientras lo hace (quitarse la camisa)» & la-C.D. & - \\
\hline 149 & $\begin{array}{l}\text { «las voces de Cachava les detiene, que } \\
\text { vuelvan les dice» }\end{array}$ & $\begin{array}{l}\text { les (detiene) - C.D. } \\
\text { les (dice) - C.I. }\end{array}$ & LEÍSMO \\
\hline 150 & «una escopeta ya podrá prestarles» & les - C.I. & - \\
\hline 151 & $\begin{array}{l}\text { «el sereno les saluda después de mirarles (a } \\
\text { ellos)» }\end{array}$ & $\begin{array}{l}\text { les (saluda) - C.D } \\
\text { (mirar)les - C.D. }\end{array}$ & $\begin{array}{l}\text { LEÍSMO } \\
\text { LEÍSMO } \\
\text { Con estos verbos, la función } \\
\text { del pronombre es problemáti- } \\
\text { ca, ya que su función puede } \\
\text { ser tanto la de complemento } \\
\text { directo como indirecto. Nos } \\
\text { inclinamos por la función de } \\
\text { complemento directo, ya que } \\
\text { son oraciones que aceptan la } \\
\text { forma pasiva, aunque esta no } \\
\text { sea una prueba definitoria. }\end{array}$ \\
\hline 152 & «dice a un amigo que se le acerca» & le - C.I. & - \\
\hline 153 & «salió Crispín...le cogoí el farol que traía» & le - C.I. & - \\
\hline 154 & $\begin{array}{l}\text { «pasé por el sitio donde le vi a Isabel el } \\
\text { primer día» }\end{array}$ & le-C.D. & $\begin{array}{l}\text { LEÍSMO } \\
\text { DUPLICACIÓN }\end{array}$ \\
\hline 155 & «que alegría me dio volverle a ver (a ella)» & le - C.D. & LEÍSMO \\
\hline 156 & $\begin{array}{l}\text { «pero yo le entiendo (a ella) y le adoro (a } \\
\text { ella)» }\end{array}$ & $\begin{array}{l}\text { le (entiendo) - C.D. } \\
\text { le (adoro) - C.D. }\end{array}$ & $\begin{array}{l}\text { LEÍSMO } \\
\text { LEÍSMO }\end{array}$ \\
\hline 157 & «(a ella) le va muy bien el traje neǵro» & le - C.I. & - \\
\hline 158 & $\begin{array}{l}\text { «(a ella) no se le calculan los años, le faltan } \\
\text { dos o tres para setenta (a ella)» }\end{array}$ & $\begin{array}{l}\text { se le (calculan) - C.I. } \\
\text { le (faltan) - C.I. }\end{array}$ & - \\
\hline 159 & $\begin{array}{l}\text { «aquella noche le encontré (a ella) como el } \\
\text { otro verano» }\end{array}$ & le - C.D. & LEÍSMO \\
\hline
\end{tabular}




\begin{tabular}{|c|c|c|c|}
\hline & Frase & $\begin{array}{l}\text { Pronombre clítico/ } \\
\text { función }\end{array}$ & Variación sintáctica \\
\hline 160 & «a los pies le dormía Cholín» & le - C.I. & - \\
\hline 161 & $\begin{array}{l}\text { «y que le salían (a ella) las rosas mejor que a } \\
\text { nadie» }\end{array}$ & le - C.I. & - \\
\hline 162 & «Isabel le solía ayudar en eso (a ella)» & le - C.D. & LEISSMO \\
\hline 163 & «mirando que todo le reluzea en orden» & le - C.I. & - \\
\hline 164 & «pero le pude contestar a tiempo (a ella)» & le - C.I. & - \\
\hline 165 & «y cuadros que le tocaron a la tía» & le - C.I. & DUPLICACIÓN \\
\hline 166 & $\begin{array}{l}\text { «y lo encontró (un cuadro) en la casa de La } \\
\text { Rioja» }\end{array}$ & lo - C.D. & - \\
\hline 167 & «le pregunté (a la tía)» & le - C.I. & - \\
\hline 168 & $\begin{array}{l}\text { «Gertrudis... "el jauntxo ya está aquî" les } \\
\text { gritaba a las otras» }\end{array}$ & les - C.I. & DUPLICACIÓN \\
\hline 169 & «a Gertrudis le gusta que yo sea el heredero» & le - C.I. & - \\
\hline 170 & $\begin{array}{l}\text { «"de éste todo ha de ser", les decía a las } \\
\text { otras» }\end{array}$ & les - C.I. & DUPLICACIÓN \\
\hline 171 & $\begin{array}{l}\text { «no quiere que a ellos pase "ni una teja... ni } \\
\text { un ochavo", seǵún le han oído» }\end{array}$ & le - C.I. & - \\
\hline 172 & «una vez mamá le dijo a papá» & le - C.I. & DUPLICACIÓN \\
\hline 173 & $\begin{array}{l}\text { «y terminar la carta que la dejé para } \\
\text { almorzar» }\end{array}$ & la - C.D. & - \\
\hline 174 & $\begin{array}{l}\text { «a la tía le ha parecido Pitusa siempre } \\
\text { prodiǵiosa» }\end{array}$ & le - C.I. & DUPLICACIÓN \\
\hline 175 & «a uno le deja con la boca abierta cuando» & le - C.D. & LEÍSMO DUPLICACIÓN \\
\hline 176 & $\begin{array}{l}\text { «no mueve el puño casi y da sólo un golpecito } \\
\text { seco para arriba, como un estirón apenas. } \\
\text { Entonces hace un aro en el aire el cordoncito } \\
\text { verde y iclak!, la tía encaja la bola y no lo has } \\
\text { visto» }\end{array}$ & lo - C.D. & - \\
\hline 177 & $\begin{array}{l}\text { «se hizo un cigarro y me dijo mientras (lo) } \\
\text { liaba» }\end{array}$ & & $\begin{array}{l}\text { SUPRESIÓN DEL } \\
\text { PRONOMBRE LO }\end{array}$ \\
\hline 178 & «"sí, Chomin" -le contesté» & le - C.I. & - \\
\hline 179 & $\begin{array}{l}\text { «le dijo Pili (a Pitusa) que había sido un héroe } \\
\text { y ella le adoraría (a él)» }\end{array}$ & $\begin{array}{l}\text { le (dijo) - C.I. } \\
\text { le (adoraría) - C.D. }\end{array}$ & LEÍSMO \\
\hline 180 & «Pitusa le explicó» & le - C.I. & - \\
\hline 181 & $\begin{array}{l}\text { «luego hablaron de cuando Isabel me ǵritó } \\
\text { "Pedrito valiente" porque ellas se lo oyeron» }\end{array}$ & lo - C.D. & - \\
\hline 182 & $\begin{array}{l}\text { «supo que me mandaban a Andía porque } \\
\text { Pitusa se lo dijo» }\end{array}$ & lo - C.D. & - \\
\hline
\end{tabular}




\begin{tabular}{|c|c|c|c|}
\hline & Frase & $\begin{array}{l}\text { Pronombre clítico/ } \\
\text { función }\end{array}$ & Variación sintáctica \\
\hline 183 & $\begin{array}{l}\text { «vino a ver la tetera que les habíamos } \\
\text { comprado a los rusos» }\end{array}$ & les - C.I. & DUPLICACIÓN \\
\hline 184 & $\begin{array}{l}\text { «que hubiese aparecido Isabel para que yo la } \\
\text { hubiese visto» }\end{array}$ & la - C.D. & - \\
\hline 185 & $\begin{array}{l}\text { «estuve como en la prisión y ella vaya si lo } \\
\text { sabía» }\end{array}$ & lo - C.D. & - \\
\hline 186 & «le tocaba (a ella) siempre hacer de reina» & le - C.I. & - \\
\hline 187 & $\begin{array}{l}\text { «así que decidí... ponerme con voluntad de } \\
\text { hierro...me lo admiraba Joxe Mari» }\end{array}$ & lo - C.D. & - \\
\hline 188 & $\begin{array}{l}\text { «darles (a ellas) algún beso y tocarlas (a } \\
\text { ellas)» }\end{array}$ & $\begin{array}{l}\text { (dar)les - C.I. } \\
\text { (tocar)las - C.D. }\end{array}$ & - \\
\hline 189 & $\begin{array}{l}\text { «me propuse a seguir bastante el plan...y que } \\
\text { ni lo empecé» }\end{array}$ & lo- C.D. & - \\
\hline 190 & «le escribí a Joshe Mari consultándole» & le - C.I. & DUPLICACIÓN \\
\hline 191 & $\begin{array}{l}\text { «por la mañana le dijeron a Gertrudis las } \\
\text { pescaderas» }\end{array}$ & le - C.I. & DUPLICACIÓN \\
\hline 192 & «yo le dije (a ella)» & le - C.I. & - \\
\hline 193 & $\begin{array}{l}\text { «la sorguuiña...le hablaba (a ella) y le dijo (a } \\
\text { ella) cosas» }\end{array}$ & $\begin{array}{l}\text { le (hablaba) - C.I. } \\
\text { le (dijo) - C.I. }\end{array}$ & - \\
\hline 194 & $\begin{array}{l}\text { «me lo tiene prohibido (desayunar en la } \\
\text { cocina)» }\end{array}$ & lo- C.D. & - \\
\hline 195 & $\begin{array}{l}\text { «y se forma el alguito que le gustaba tanto a } \\
\text { Isabel» }\end{array}$ & le - C.I. & DUPLICACIÓN \\
\hline 196 & $\begin{array}{l}\text { «yo le decía eso (a ella)...yo entonces le decía } \\
\text { (a ella)» }\end{array}$ & $\begin{array}{l}\text { le (decía) - C.I. } \\
\text { le (decía) - C.I. }\end{array}$ & - \\
\hline 197 & «mejor que darle a la escoba ya es» & le & $\begin{array}{l}\text { DUPLICACIÓN EN UNA } \\
\text { FRASE HECHA. USO } \\
\text { ERRÓNEO }\end{array}$ \\
\hline 198 & $\begin{array}{l}\text { «yo le puse a ella pendientes y le enseñé } \\
\text { como se hace» }\end{array}$ & $\begin{array}{l}\text { le (puse) - C.I. } \\
\text { le (puse a ella) - C.I. } \\
\text { le (enseñé) - C.I. }\end{array}$ & - \\
\hline 199 & «ella no lo sabía que eso existiese» & lo- & DUPLICACIÓN ERRÓNEA \\
\hline 200 & «ella lo echaba fuera (el rabilo)» & lo- C.D. & - \\
\hline 201 & «le hice (a ella) llorar de risa» & le - C.I. & - \\
\hline 202 & «mientras yo le levantaba (a ella)» & le - C.D. & LEÍSMO \\
\hline 203 & «le ǵritaba a la pobre Edurne» & le - C.I. & DUPLICACIÓN \\
\hline 204 & «le quería decir (a ella) “¡a coger fresas!”» & le - C.I. & DUPLICACIÓN \\
\hline 205 & «no les des, por favor, confianza (a ellas)» & les - C.I. & - \\
\hline
\end{tabular}




\subsection{Análisis de las variaciones encontradas}

\subsubsection{Cómputo estadístico de los ejemplos}

De un total de 205 frases y 235 usos de pronombres clíticos, el estudio tipológico vierte los siguientes datos:

- usos correctos: $160=68 \%$

- laísmos: $2=0,8 \%$

- leísmos: $58=24 \%$

- loísmos: 0

- omisiones de pronombres: $12=5 \%$

- recurrencias de complemento directo y suplemento: $2=0,8 \%$

- casos de leísmo dudoso (leísmo formal pero no semántico): $1=0,4 \%$

- duplicaciones (no contabilizadas en el total): $36=0,15 \%$

\subsubsection{Leísmo}

Los antecedentes de los 50 leísmos que aparecen en el texto se distribuyen de la siguiente manera:

- de persona masculino singular: $35=70 \%$

- de persona femenino singular: $10=20 \%$

- de cosa singular: $1=2 \%$

- de persona plural: $4=8 \%$

Como se puede observar, el porcentaje más elevado corresponde al leísmo de persona masculino singular, que han sido admitidos por la Real Academia de la Lengua, por lo que bien podríamos no considerarlos como tales. El resto (el 30\%) son leísmos propiamente dichos. No parece haber en estos ejemplos ni un patrón claro, ni una causa específica con la que podamos relacionar los casos que encontramos de esta desviación de la norma.

Por otro lado, los pronombres átonos de complemento siempre preceden al verbo si este está conjugado, o aparecen como sufijos en gerundios e infinitivos:

- «la señora le abrazaba» (a ella),

- «él la creía tozuda» (a ella),

- «mirándole cara a cara» (a ella),

- «¿por qué le perturbaba (a él) enviándole aquello?»,

- «al encontrarle» (a él),

- «sólo podía hacerlo él».

A partir de estos ejemplos, tampoco se deduce una causa sintáctica que dé lugar al leísmo, ya que contamos con oraciones correctas tanto leístas como no leístas; así mismo, el cambio de posición de las palabras en la oración con respec- 
to a su orden correcto no parece influir en el desarrollo del leísmo, como se puede observar en los siguientes ejemplos:

- sujeto + pronombre + verbo:

«la señora le abrazaba cariñosamente»

«Mastraga lo juǵaba» (el tresillo)

- pronombre + verbo + sujeto:

«aquí tienes al vecino que le trae una bruja»

«le decía su amigo»

- sujeto elidido:

(ella) «así le creería mejor» (a él)

(él) «la creía tozuda» (a ella)

Tal y como proponen Fernández Ordóñez (1993) y Uruburu Bidaurrazaga (1993), otra razón para esta variación podría ser semántica, por la que la variación del uso de los pronombres clíticos estaría en relación con el significado del verbo, aunque esta tampoco parece ser la causa definitiva de la distinción, tal y como podemos apreciar en los ejemplos siguientes:

- verbos mentales:

«que no le entendía» (a él)

«vosotros lo pensaréis»

- verbos físicos:

«le siguió el médico» (a él)

«encolerizado, le arrojó una piedra»

También, se podría pensar que la eufonía pudiera justificar alguno de los casos, sin embargoo, el número de ejemplos es tan reducido, que no lleǵan a ser definitorios:

la ha ofendido > «le ha ofendido» (disimilación eufónica)

«aquellos la cantan» (la vida)

Asimismo, se podría mencionar la economía lingüuística y la recurrencia de los pronombres con un complemento circunstancial, pero al igual que en el apartado anterior, el número de ejemplos con el que contamos no es relevante:

«los amigos le imitan»

«vosotros lo pensaréis»

«así le creería mejor»

«la beberán (la leche) allí fuera»

Como se puede observar, no queda muy clara cuál es la principal causa de leísmo en estos ejemplos, aunque sí se podría aventurar la razón de la recurrencia de una serie de frases en la lengua común: los hablantes utilizan con frecuencia 
un número limitado de unidades léxicas y, al hablar, es habitual que repitan inconscientemente las formas más comunes aunque sean erróneas, ya que están acostumbrados a ellas, mientras que se detienen en analizar las formas que les resultan menos habituales o más complejas. Sin embargoo, se ve necesaria la definición de un corpus más extenso para aventurarnos en la búsqueda de una causa principal para esta variación, dado el sustrato lingüuístico de los hablantes.

\subsubsection{Laísmo}

En los textos, solo contamos con dos ejemplos de laísmo, número tan exiguo que nos permitiría afirmar que el laísmo sería una variación residual:

«allí se la sintió lavar vasos»

«lo que le dolía era el temor a que la creyeran cómplice»

\subsubsection{Loísmo}

En el corpus estudiado no hay ningún ejemplo de loísmo, por lo que se podría confirmar la teoría de que el castellano del País Vasco no es loísta.

\subsubsection{Omisión de pronombres}

Otra de las variaciones que se observa en los textos es el de la omisión de los pronombres clíticos. Tal y como hemos referido anteriormente, en euskera no existe este tipo de pronombres personales, lo que lleva a los hablantes no solo a usarlos mal cuando se expresan en castellano, sino también a omitirlos cuando son necesarios.

En el corpus, la omisión aparece en pronombres con función tanto de complemento directo, como de complemento indirecto. Se debe subrayar que en la frase no puede aparecer un sintagma nominal con esta misma función, ya que estaríamos, entonces, ante una duplicación de complementos.

Las doce omisiones que aparecen en el corpus son:

- omisión de la, que en todos los casos hacen referencia a sustantivos comunes de género femenino, $33 \%$ :

«aquí traigo» (la carta)

«he tenido que cocer» (la leche)

- omisión de le o les, $8 \%$ :

«cuando el mozo preguntó» (a la chica) 
- omisión de lo, que puede hacer referencia tanto a sustantivos comunes de género masculino, como a acciones, $58 \%$ del total:

de persona: «capaz de llevar como ha dicho» (el hijo)

de cosa: «si no haces ahora» (hablar con su mujer)

\subsubsection{Duplicaciones}

La Academia de la Lengua Española define la duplicación de complementos como la «repetición de un segmento lingüístico» ${ }^{9}$ que, en nuestro caso, haría referencia a la aparición de un pronombre átono y un sintagma nominal o preposicional, referidos a la misma realidad en una misma frase. Esta variación, que aparece en castellano desde sus orígenes, es un rasgo de la lenǵua hablada, por lo que se puede considerar propio de un habla descuidada.

En el corpus estudiado, las duplicaciones se dan tanto en sintagmas con función de complemento directo, como con función de complemento indirecto, por lo que esta distinción sintáctica no supone una causa de recurrencia:

«ya le he dicho a ella»

«el gobierno lo hacían entre la etxekoandre y un morroi»

No obstante, parece haber tres causas que originan la duplicación de complementos:

- posición del sujeto al final de la frase, lo que implica la reorganización de los elementos sintácticos restantes y aparece en un $28 \%$ de los casos:

«ahí tienes al vecino cómo le trae una bruja»

«la comida del ganado la hacía la vieja madre»

- omisión del sujeto, lo que conlleva una posición diferente de los sintaǵmas, y se da en un $40 \%$ de los ejemplos:

«a tu padre le tengo en las rentas»

«le gritaba a la pobre Edurne»

- énfasis tanto de acciones como de personas, que se observa en un $28 \%$ de los casos:

acciones: «se prepare para darle vueltas al chisme»

personas: «una vez mamá le dijo a papá»

Respecto a este cómputo, parecen destacar las ocasiones en las que el pronombre se duplica por la reorganización llevada a cabo en la frase al omitirse el sujeto. Sin embargoo, la diferencia cuantitativa no parece ser definitiva.

9 https://dle.rae.es/reduplicaci\%C3\%B3n 
Hay un único ejemplo que difiere de los anteriores, ya que no hay elisión del sujeto, que aparece en su lugar correspondiente, ni tiene un claro sentido enfático. La única razón que le podemos encontrar es que el complemento indirecto es, en realidad, el sujeto actante de la acción verbal:

«alterar... aquel régimen ya establecido le parecía al disminuido (Mortero) empresa inalcanzable».

El hecho que se podría apuntar como causa de este fenómeno pudiera ser la ultracorrección, o la adaptación de los pronombres a un paradigma que se considera correcto, pero que no lo es. Sin embargo, el corpus es limitado y se necesitarían más ejemplos de uso para confirmarlo.

\section{Conclusión}

Aunque somos conscientes de que el corpus de estudio no es muy amplio, con este trabajo hemos pretendido analizar la variación de los pronombres clíticos en un campo en el que no ha sido estudiado en profundidad: las obras literarias de autores de segundo nivel. Korkostegi (1992), en su estudio sobre estos mismos fenómenos en la obra de Pío Baroja, o Paasch-Kaiser (2015), en su obra sobre el castellano en Getxo, cubren esta realidad en otros dos ámbitos de lenǵuaje, a saber, literario y coloquial, pero carecemos de referencias a ese lenguaje que se cubre con tintes literarios, de mano de autores que no forman parte de los literatos de primera línea.

Partíamos de dos afirmaciones. La primera era que «en el País Vasco es general el leísmo de persona masculina, pero también el de persona femenina» (Fernández Ulloa, 1997, p. 203) y la segunda se refería al carácter de jerǵa literaria que caracterizaba al lenguaje utilizado en el corpus seleccionado. Tras el estudio del mismo y el análisis de la recurrencia del uso de los pronombres personales átonos, hemos podido apuntar a una confirmación de la tendencia al leísmo, lo que afianzaría la hipótesis antes apuntada de que el castellano del País Vasco es leísta. Hemos de subrayar, así mismo, la situación temporal de las narraciones, primeras décadas del siǵlo XX, debido al hecho de que en ese momento había hablantes cuya lengua materna era el vascuence, pero que también conocían y se expresaban en castellano con una clara adscripción a la definición de bilingüue dominante (Lamber, 1955).

Consideramos que sería un trabajo interesante realizar este mismo análisis en cada uno de los autores elegidos, lo que puede quedar para futuras investigaciones. 


\section{Referencias}

Alcina, J., y Blecua, J. M. (1975). Gramática Española. Barcelona: Ariel.

Aranaz Castellanos, M. (1969). Cuadros vascos. Bilbao: Editorial Librería Vascongada Villar

Arzadun, J. (1921). Cuentos vascos. Bilbao: Editorial Vizcaína.

Camús Bergareche, B., y Gómez Seibane, S. (2015). Nuevos datos sobre la omisión de objetos en el castellano del País Vasco. Círculo de Lingüística Aplicada a la Comunicación, 61, 211-236.

Cano-Aguilar, R. (1998). La aportación de Lapesa a la sintaxis histórica del nombre en español. Philologia hispalensis, 12(2), 17-42.

Echenique Elizondo, M. T. (1981). El sistema referencial en español antiguo: laísmo, leísmo, loísmo. Revista de Filología Española, 61(1/4), pp 113-157. Recuperado de http://revistadefilologiaespañola.revistas.esic.es/index.php/rfe/article/ view/612/688

Echenique Elizondo, M. T. (2016). Lengua española y lengua vasca: una trayectoria histórica sin fronteras. Revista de Filologías, 34, 235-252.

Fernández-Ordóñez, I. (1993). Leísmo, laísmo y loísmo: Estado de la cuestión. En O. Fernández Soriano (Ed.), Los pronombres átonos. Madrid: Taurus Universitaria.

Fernández-Ordóñez, I. (2001). Hacia una dialectología histórica. Reflexiones sobre la historia del leísmo, laísmo y loísmo. Universidad Autónoma de Madrid, Biblos-e Archivos. Recuperado de https://repositorio.uam.es/handle/10486/660431

Fernández Ulloa, T. (1997). Lenguas en contacto: caracterización del castellano del País Vasco y actitudes hacia la lengua. Fundación Sancho el Sabio. Recuperado de: https://www.euskalmemoriadigitala.eus/handle/10357/40569

Fernández Ulloa, T. (2006). Influencias morfosintácticas de la lengua vasea en el castellano actual: orden de elementos, condicional por subjuntivo y pronombres complemento átonos de $3^{\text {a }}$ persona. Ohienart, 21, 73-99.

Irigoyen Gerrikabeitia, J. de (1936). Los tremendos de Kamala. Bilbao: Artes Gráficas de Grijelmo.

Korkostegi Aranguren, M. J. (1992). Pío Baroja y la gramática: estudio específico del leísmo, laísmo y loísmo y la duplicación de objetos. Bilbao: Universidad de Deusto.

Lambert, W. E. (1955). Measurement of the linguistic dominance in bilinguals. Journal of Abnormal and Social Psychology, 50, 197-200.

Lapesa, R. (1964). Los casos latinos: restos sintácticos y sustitutos en español. BRAE, 44(171), 57-105. Recuperado de http://revistas.rae.es/brae/article/view/91/149

Líbano Zumalacárregui, Á. (1997). Contribución de Unamuno a la dialectología vizcaína. Cuadernos de la Cátedra de Miguel de Unamuno, 32, 125-141.

Mendieta-Lombardo, E., y Molina, I. (1995). Juicios de gramaticalidad ante una estructura morfosintáctica del español hablado en el País Vasco. Mundaiz, 50, 25-34. Recuperado de https://www.researchgate.net/publication/282243369_Juicios_ de_gramaticalidad_ante_una_estructura_morfosintactica_del_espanol_hablado_en_el_Pais_Vaseo 
Miranda Hidalgo, B. (1994). La norma de los clíticos en las gramáticas de los siglos XVI y XVII. Anuario de estudios filológicos, 17, 351-368.

Paasch-Kaiser, G. (2015). El castellano de Guetxo. Berlin: De Gruyter.

Sagüiés, M. (2006). Gramática elemental vasca: gramática comparada. 13ª ed. San Sebastián: Txertoa.

Saiz Valdivieso A. C. (2010). Rafael Sánchez Mazas. El espejo de la memoria. Bilbao: Ed. Muelle de Uribitarte.

Sánchez Mazas, R. (1968). La vida nueva de Pedrito de Andía. Madrid: Planeta.

TreffersDaller, J. (2015). The construct of language dominance, its operationalization and measurement. En C. SilvaCorvalan y J. TreffersDaller (Eds.), Language Dominance in Bilinguals: Issues of Measurement and Operationalization (pp. 235-265). Cambridge: Cambridge University Press. Recuperado de http:// centaur.reading.ac.uk/39020/

Unamuno, M. de (1958). El dialecto bilbaíno (R.I.P.). En M. de Unamuno, Obras Completas. Tomo VI. De la raza y la lengua. Barcelona: Ed. Vergara.

Urrutia Cárdena, H. (2003). Los clíticos de tercera persona en el País Vasco. CAUCE, Revista de Filología y su Didáctica, 26, 517-538. Recuperado de https://cve. cervantes.es/literatura/cauce/pdf/cauce26/cauce26_22.pdf

Uruburu Bidaurrazaga, A. (1993). Estudios sobre leísmo, laísmo y loísmo. Córdoba: Universidad de Córdoba.

Zarate, M. (1976). Influencias del vascuence en la lengua castellana: A través de un estudio del elemento vasco en el habla coloquial de Chorierri-Gran Bilbao. Bilbao: La Gran Enciclopedia Vasea. 